\title{
Isolation and identification of bacteria and parasites in glass eel (Anguilla spp.)
}

\author{
Septyan Andriyanto ${ }^{1,}{ }^{*}$ Hessy Novita $^{1}$, Tuti Sumiati ${ }^{1}$, and Taukhid ${ }^{1}$ \\ ${ }^{1}$ Research Station For Fish Disease Control, Research Institute for Freshwater Aquaculture and \\ Fisheries Extension, Jl. Perikanan Raya No. 13 Pancoran Mas, Depok 16436, Indonesia
}

\begin{abstract}
The disease is the main agent that causes mortality of fish, especially during seed stages. The research aimed to find out bacteria and parasitic speciesin glass eel, Anguilla spp. Bacterial identification was carried out by a biochemical method. The prevalence of bacterial species was calculated using the El-Gohary et al. (2020) formula, while the results of bacterial identification from glass eel were Aeromonas spp., Vibrio spp., Enterococcus spp., Staphylococcus spp., Planococcus spp., Lactobacillus spp., Listeria spp., Citrbacterfreundii, Neisseria spp., Pseudomonas aeruginosa, Kurthia spp., Streptococcus spp., and Corynebacterium spp. It was found that the five highest prevalence rate was for Listeria spp. (39.64\%), followed by Aeromonas spp. (26.13\%), Staphylococcus spp. $(16.22 \%)$, Corynebacterium spp. (5.41\%), Lactobacillus spp. (2.70\%), and the lowest prevalence rate was Streptococcus spp. (0.90\%). The type of parasitic pathogen obtained was Trichodina spp. (2,70\%), Dactylogyrus spp. (2,70\%) and Gyrodactylus spp. $(2,70 \%)$. Bacterial and parasites identified in glass eels need further verification on the epizootiology characteristic of each pathogenic agent.
\end{abstract}

\section{Introduction}

The disease is one of the main causes of fish death, especially during the seed phase. The disease can also be caused by pathogens carried by carrier fish that infect healthy fish. Pathogens that can cause fish disease include viruses, bacteria, parasites, and fungi [17]. Eel (Anguilla spp.) is a cultivated fish with high economic value with delicious and distinctive meat taste and higher nutritional content than other economically important fish species. In eel culture, the high mortality in the stages from glass eel to Elver, which reaches $50-80 \%$, is not known with certainty. Several types of parasitic and bacterial pathogens in eel but have not specifically explained the epizootiology of each type of pathogen found. Temporary suspicion, the main cause of this condition, among others, is due to post-transportation syndrome and co-infection of several infectious disease agents at the beginning of eel rearing $[4,5,20]$.

Fish disease control systems and strategies caused by highly contagious, endemic, and deadly infectious pathogens in fish culture will not succeed if they are carried out

\footnotetext{
* Corresponding author: septian08@yahoo.com
} 
conventionally, partially, and without information regarding the characteristics and epidemiology of the main pathogen causing the disease. Limited information about diseases that infect glass eels can be a problem in controlling the disease in the future. Identification is one of the efforts to determine the type of disease-causing pathogen needed to determine the right method to overcome potential diseases in eel. The research aims to find out the bacteria and parasitic species in glass eel, Anguilla spp.

\section{Materials and methods}

Identification of bacteria and parasites was carried out at the Fish Health Laboratory, Research Station For Fish Disease Control, Research Institute for Freshwater Aquaculture and Fisheries Extension (BRPBATPP), Ministry of MarineAffairs, and Fisheries (KKP)in May-October 2019. The glass eel sampling was carried out in Palabuhanratu Bay, Sukabumi. Sampling was carried out in the 3 locations, namely, the Cimandiri River (41 samples), the Cikaso River (35 samples), and the Cibuni River (35 samples). Glass eels with an average body weight of $0.14 \pm 0.03 \mathrm{~g}$ were used in the identification of bacteria and parasites.

\subsection{Bacterial identification}

Glass eel samples were taken directly from the water under normal conditions and without physical damage. Bacterial isolation was taken from each glass eel sample on Tryptone Soy Agar (TSA) and Brain Heart Infusion Agar (BHIA) medium. Isolation was carried out under aseptic and sterile conditions. Isolation by culturing eel scratch marks that have been washed in medium and incubated $24-48$ hours at $28^{\circ} \mathrm{C}$. Developed colonies were further purified 3 to 4 times using the one scratching method in the same medium step to step until uniform colonies were obtained. Observation of the morphology of the purified and growing bacterial colonies on the culture medium macroscopically. The next step is bacterial biochemical testing that is consisted of Gram staining, motility, oxidase, catalase, oxidative fermentative $(\mathrm{O} / \mathrm{F})$, selective media testing, and testing using KIT API 20 E for Aeromonas spp. bacteria. Bacterial characterization was carried out conventionally through biochemical tests using the method of [1]. The prevalence of bacteria was calculated using the following formula [23]:

$$
\text { Prevalence of bacteria }(\%)=\frac{\text { Number of fish hosts }}{\text { Total number of examined fish }}
$$

\subsection{Parasites identification}

Parasite examination, preparation, and observation procedures were carried out according to the standard work instructions for the Parasite Examination Method at Fish Health Laboratory BRPBATPP. The parasite species found was placed on a glass object, observed meristically-morphometrically using a microscope, and identified according to [10, 13, 2, 21]. Test samples that cannot be examined directly at the sampling location are fixed individually in a 5-10\% Neutral Buffered Formalin (NBF) solution. Analysis was carried out on the prevalence of parasitic species calculated according to the formula developed by [14]:

$$
\text { Prevalence }=\frac{\text { Number of fish hosts by parasites }}{\text { Total number of the observed fish }} \times 100 \%
$$




\section{Results}

Based on the identification results of all glass eel samples, 13 types of bacteria were identified. Three types of bacteria with a prevalence value of $>15 \%$ were Listeria spp., Aeromonas spp., and Staphylococcus spp. While the bacteria with the lowest prevalence $<1.0 \%$ were Enterococcus spp. and Streptococcus spp. Meanwhile, three types of parasites identified in glass ell were Trichodina spp., Dactylogyrus spp., and Gyrodactylus spp. with a low prevalence $(2.7 \%)$ (Table 1$)$.

Table 1. Bacterial and parasitic species identified in glass eels (Anguilla spp.)

\begin{tabular}{|c|c|c|c|c|}
\hline \multirow[b]{2}{*}{$\sum$ Samples } & \multicolumn{2}{|c|}{ Bacteria } & \multicolumn{2}{|c|}{ Parasite } \\
\hline & Species & Prevalence $(\%)$ & Species & $\begin{array}{c}\text { Prevalence } \\
(\%)\end{array}$ \\
\hline \multirow[t]{13}{*}{111} & Aeromonas spp. & 26.13 & Trichodina spp. & 2.70 \\
\hline & Vibrio spp. & 1.80 & Dactylogyrus spp. & 2.70 \\
\hline & Enterococcus spp. & 0.90 & Gyrodactylus spp. & 2.70 \\
\hline & Staphylococcus spp. & 16.22 & & \\
\hline & Planococcus spp. & 1.80 & & \\
\hline & Lactobacillus spp. & 2.70 & & \\
\hline & Listeria spp. & 39.64 & & \\
\hline & Citrobacterfreundii & 1.80 & & \\
\hline & Neisseria spp. & 1.80 & & \\
\hline & Pseudomonas aeruginosa & 1.80 & & \\
\hline & Kurthia spp. & 1.80 & & \\
\hline & Streptococcus spp. & 0.90 & & \\
\hline & Corynebacterium spp. & 5.41 & & \\
\hline
\end{tabular}

\section{Discussion}

Several researchers have conducted similar studies, [20] reported three types of dominant bacteria in the glass eel stage, namely Aeromonas hydrophila, Streptococcus agalactiae, and Listeria grayi. Research in Korea [9] found the bacteria Edwardsiella tarda, A. hydrophila, Citrobacter freundii, A. veronii, Listonella anguillarum, Plesiomonas shigelloides, and Pseudomonas anguiliseptica in cultured eel. Also [5] reported several types of bacteria that infect eels in the Netherlands, including Vibrio vulnificus, Edwardsiella tarda, Aeromonas sobria, A. hydrophila, Pseudomonas anguilliseptica, and Flavobacterium spp. Infection with Vibrio anguillarum, P. anguilliseptica, A. hydrophila, E. tarda, Flavobacterium columnare, and $A$. salmonicida was found in Japanese eels.

Listeria spp. Most commonly found in the study with a prevalence of $39.64 \%$. The morphology of the colony of Listeria spp. It is transparent in color, has convex bumps, and is circular, while the cell morphology is rod-shaped and gram-positive. This type of bacteria is found in fish that live in an environment contaminated by pollution and sewage and is a bacterial pathogen for humans and animals. While [6] mentioned Listeria spp. Including gram-positive short rods and sometimes almost cocci shape. This bacteria is sporeless, motile with some flagella when grown at $20-25^{\circ} \mathrm{C}$ and non-motile when grown at $30-37^{\circ} \mathrm{C}$. Listeria spp. on nutrient agar is convex and transparent. At the same time, the catalase test has positive results and negative oxidase.

Aeromonas spp was the next dominant bacterial species with a prevalence value of $26.13 \%$. The morphology of the Aeromonas spp. The colony is cream-colored, convex bumps and circular shape, while the cell morphology is rod-shaped and gram-negative. These bacterial species were identified based on biochemical tests indicated by oxidase-positive, catalase-positive, gram-negative, $\mathrm{O} / \mathrm{F}$ positive, motile, positive $\mathrm{RS}$, and capable of 
fermenting glucose, sucrose, and lactose. [8] reported that Aeromonas spp. were gramnegative, oxidase-positive, and catalase-positive. These bacteria can also ferment several sugars such as glucose, fructose, maltose, and trehalose. The result of fermentation can be an acid compound or an acid compound with gas. On nutrient agar, after 24 hours, bacterial colonies with a diameter of 1-3 mm were observed, which were convex, smooth, and bright. Similarly, [19] stated that the colony morphology of Aeromonas hydrophila is cream-colored, convex elevation, and has smooth edges, while the cell morphology is rod-shaped and gramnegative.

Aeromonas hydrophila infection causes an acute bacterial disease commonly called "Red Disease" which infects all ages and types of freshwater fish and can even result in death reaching $100 \%[11,18]$. Clinical symptoms of fish that $A$. hydrophila attacks include reddish sores on the body, damage and decay on the fins (red sores on the anal fin, dorsal fin, scabs on the dorsal fin, and tail fin), protruding eyes, whitish gills, and belly filled with fluid [15]. During the infection process, $A$. hydrophila bacteria produce enzymes that degrade the chitin layer of infected fish so that bacteria can easily enter the fish's body. A. hydrophila also secretes enzymes such as lecithinase that enter the bloodstream and flow directly to the kidneys to multiply [12].

[7] stated that fish infected with Aeromonas hydrophila resulted in weakened body defenses. Protection of the body from bacterial infections, fish, will secrete mucus continuously, resulting in increased body metabolism and more energy consumption. This situation makes it easier for bacteria to enter and infect by releasing toxins through open places such as gills, tails, or fins. Meanwhile, according to [3], Aeromonas hydrophila is included in the group of pathogenic bacteria with high virulence. The level of virulence of these bacteria is determined by the ability of bacteria to produce certain enzymes and toxins that play a role in the process of invasion and infection. As virulence factors, chitinase, lecithinase, and hemolysin produced by $A$. hydrophila work by degrading tissue and causing injury and bleeding in the host fish. Likewise, [22] reported that fish infected with Aeromonas hydrophila bacteria generally experience widespread bleeding on the skin surface (hemorrhagic septicemia), which is followed by the appearance of open sores (ulcers) on the body surface or into the tissues. In addition, in several other types of fish, clinical signs are often found, such as loss of dorsal and caudal fin and swelling of the abdomen and filled with fluid (dropsy), which is followed by death.

According to [16] that Trichodina, Vorticella, Anguillicola and Spirocamallanus parasites were found in the glass eel Anguilla bicolor from the Serayu River, Central Java. A similar study was conducted by [4] concluded that Gyrodactylus anguillae ectoparasites and Vibrio vulnificus bacteria were the two main pathogens that cause disease and death in eel (Anguilla anguilla) cultivation in Egypt.

Based on available data and information, it is still very early to predict which types of pathogens have the most role and cause high mortality in the maintenance of glass eel. Bacterial and parasites identified in glass eel need further verification on the epizootiology characteristic of each pathogenic agent.

\section{Conclusion}

Based on the results of bacterial identification from glass eel, Aeromonas spp., Vibrio spp., Enterococcusspp., Staphy lococcus spp., Planococcus spp., Lactobacillus spp., Listeria spp., Citrobacterfreundii, Neisseria spp., Pseudomonas aeruginosa, Kurthia spp., Streptococcus spp., and Corynebacterium spp. Parasitic species identified was Trichodinas pp., Dactylogyrus spp. and Gyrodactylus spp. 


\section{References}

1. B. Austin, D. A. Austin, Bacterial fishpathogens: diseases in farmed and wildfish (Ellis Horwood Ltd., Chichester, 1993)

2. S. Chinabut, L. H. S. Lim, Raffles Bull. Zool. 41, 1 (1993)

3. F. A. Del Coral, E. B. Shotts, J. Brown, J. Fish Dis. 13 (1990)

4. M. Y. Elgendy, A. M. Kenawy, A. E. N. El-Deen, Comun. Sci.7, 1 (2016)

5. O. L. M. Haenen, I. Mladineo, R. Konecny, M. Yoshimizu, D. Groman, P. Muñoz, A. Saraiva, S. M., Bergmann, S. J. van Beurden, Bull. Eur. Assoc. Fish Pathol. 32, 3 (2012)

6. J. G. Holt, N. R. Krieg, P. H. A. Sneath, J. T. Stanley, S.T. William, Bergey's manual of determinative bacteriology (Ninth Ed. A Wolters Kluwer Company, Philadelphia, 1994)

7. G. Huys, P. Kampfer, M. J. Albert, I. Kuhn, R. Denys, J. Swings, Int. J. Syst. Evol. Microbiol.52(2002)

8. J. H. Isonhood, M. Drake, J. Food Prot. 65, 3(2002)

9. S. J. Joh, H. A. Eun, J. L. Hye, W.S. Gee, H. K. Jun, G. P. Choi, Vet. Microbiol. 163, 1$2(2013)$

10. Kabata, Z., Parasites and diseases of fish cultured in the tropics (Taylor and Francis Ltd., Philadelphia, 1985)

11. M. O. Kamelia, A. M. Laila, WJFMS. 1, 4 (2009)

12. R. Kusdarwati, Kismiyati, Sudarno, H. Kurniawan, Y. T. Prayogi, IOP Conf. Ser. Earth and Environ. Sci.55,1-7 (2017)

13. J. Lom, I. Dyková, Protozoan parasites of fishes (Elsevier Science Publisher B.V., Amsterdam, 1992)

14. L. Margolis, G. W. Esch, J. C. Holmes, A. M. Kuris, G. A. Schad, J. Parasitol. 68, 1 (1982)

15. Pramudita, Sarjito, S. B. Prayitno, J. Aquaculture Management and Technology 2, 2 (2013)

16. I. Pratama, S.B. Prayitno, H. Syakuri, Omni-Akuatika, 15, 1, 81-92(2019)

17. M. Sharma, A. B. Shrivastav, Y. P. Sahni, G. Pandey, Int. Res. J. Phar, 3, 7(2012)

18. Taukhid, U. Purwaningsih, D. Sugiani, T. Sumiati, A. M. Lusiastuti, J. Ris. Akuakultur 10, 4 (2015)

19. D. Wahjuningrum, R. Astrini, M. Setiawati, J. Akuakultur Indonesia (JAI).12, 1 (2013)

20. D. Wahjuningrum, A. M. Hidayat, T. Budiardi, J. Akuakultur Indonesia (JAI). 17, 1 (2018)

21. H. H. Williams, A. Jones, Parasitic worms of fish (Taylor and Francis, London, 1994)

22. K. N. Yuasa, M. B. Panigoro, Kholidin, Fish disease diagnosis guide: fish disease diagnosis techniques for freshwater aquaculture in Indonesia (BBAT Jambi, Jambi, 2003)

23. F. A. El-Gohary, E. Zahran, A. El-Gawad, A. Eman, A. H. El-Gohary, F. M Abdelhamid, A. El-Mleeh, E. K. Elmahallawy, M. M. Elsayed, Animals, 10, 8 (2020) 